\title{
Assessment of Water Quality Status of Guruvayur Municipality
}

\author{
P. S. Harikumar, Anisha Aravind, Sandra Vasudevan \\ Water Quality Division, Centre for Water Resources Development and Management, Kozhikode, India \\ Email:drpshari@yahoo.co.in
}

How to cite this paper: Harikumar, P.S., Aravind, A. and Vasudevan, S. (2017) Assessment of Water Quality Status of Guruvayur Municipality. Journal of Environmental Protection, 8, 159-170. https://doi.org/10.4236/jep.2017.82013

Received: December 23, 2016

Accepted: February 21, 2017

Published: February 24, 2017

Copyright (c) 2017 by authors and Scientific Research Publishing Inc. This work is licensed under the Creative Commons Attribution International License (CC BY 4.0).

http://creativecommons.org/licenses/by/4.0/

(c) (i) Open Access

\begin{abstract}
Groundwater is an essential and vital component of our life support system. The deterioration in the groundwater quality due to geogenic and anthropogenic activities has drawn great attention as it is the major alternate source of domestic and drinking water supply. Groundwater and surface water samples collected from various locations in Guruvayur were analysed for selected physico-chemical and bacteriological parameters by adopting APHA standard methods. The results of the analysis indicated the chemical and bacteriological contamination due to the disposal of solid, organic and septic wastes in the surface water samples of Chakkamkandam, Palayur and Edappally which are the various locations in Gurauvayur. Also the groundwater samples of Guruvayur were contaminated. The study revealed that, the water samples examined were found to be above the permissible limits of Bureau of Indian Standards (BIS). The sewage inlets that open directly to the water body are the major source of pollutants. The monitoring of various water bodies indicates the importance of taking appropriate measures to treat the water resources before either discharged to wetlands or consumed by human beings. It is also recommended to continue the monitoring periodically to assess the pollution status of the area.
\end{abstract}

\section{Keywords}

Water Quality, Chakkamkandam, Palayur, Edappully, Guruvayur

\section{Introduction}

All the 44 rivers originating from the Western Ghats of Southern district of Kerala, India are facing slow ecological death and losing their natural flow pattern due to combined impact of various interventions in the catchments and inside the river channel including deforestation of the catchment areas, forest fragmentation, blocking the flows by dams, encroachment and massive mining of 
hills [1]. Water quality is a critical factor that controls human health; and human activities are the major cause of surface and groundwater pollution [2]. As Earth's population continues to grow, people are putting ever-increasing pressure on the planet's water resources. In a sense, our oceans, rivers, and other inland waters are being "squeezed" by human activities-not so they take up less room, but so their quality is reduced. It has been suggested that water pollution is the leading worldwide cause of deaths and diseases, and that it accounts for the deaths of more than 14,000 people daily [3]. Protection of groundwater is a major environmental issue since the importance of water quality on human health has attracted a great deal of interest in recent years [4].

Kerala, a southern State of India, is one among the most thickly populated region in the world and the population is increasing at a rate of $14 \%$ per decade. As a result of the measures to satisfy the needs of the huge population, the rivers of Kerala have been increasingly polluted from the industrial and domestic waste and from the pesticides and fertilizer in agriculture. Industries discharge hazardous pollutants like phosphates, sulphides, ammonia, fluorides, heavy metals and insecticides into the downstream reaches of the river. A study was reported [5] on the measurement of the impact of a municipal solid waste landfill on groundwater quality around Njelianparamba, a solid waste dumping site in Kozhikode district, Kerala state, India. One of the major problems associated with dumping of municipal solid waste landfill is the release of leachate and its impact on surrounding groundwater

Guruvayur or Gurupavanapuri is a municipal town in Thrissur district, of Kerala state in India. It houses the Guruvayur Sree Krishna Temple, the fourth largest temple in India in terms of the number of devotees visiting per day. Guruvayoor is a Grade-1 Municipality. The Municipality has a total population of 20,216 with a population density of 31,14 per $\mathrm{km}^{2}$. Guruvayur assembly constituency is part of Trissur. Guruvayur Sree Krishna Temple attracts millions of devotees from all over India and abroad every year. The small township has become the No.1 destination not only for the devotees of Lord Krishna but also for foreigners coming to India.

Presently, Guruvayur municipality faces many problems of water pollution. The discharge of untreated domestic and commercial effluents in to the backwater has resulted in severe environmental problems such as deteriorated water quality and health and livelihood related issues in the neighbouring villages. Chakkamkandam is a village adjacent to the great temple town of Guruvayur in Kerala. The residents of this village are agriculturists, coir workers, and fishermen. Guruvayur Township is situated in their serene landscape depriving them the use of fresh water, clean air and unpolluted land. There are 3000 families living around Chakkamkandam. The canal from Guruvayur to Chakkamkandam (Valiyathodu) is now an open sewer line with human excreta and all forms of water being carried through this to the village. The canal runs through the municipal area for almost two kilometres and then enters Thykad panchayat, where it travels two more kilometres, before reaching the Chakkamkandam backwater. 
This canal carries tonnes and tonnes of disintegrated waste polluting the backwater and Guruvayur area as a whole.

Most commercial establishments and apartments do not have properly functional septic tanks and discharge the raw sewage directly into open drains. The drains, Valiyathod and Cheriyathod flow three kilometres through the town before joining the back waters of Chakkamkandam. The discharge of untreated domestic and commercial effluents in to the backwater has resulted in severe environmental problems such as deteriorated water quality, health and livelihood related issues in the neighbouring villages.

According to the estimates of Guruvayur municipality, over 3.5 crore devotees visit Guruvayur every year. The people of Chakkamkandam are forced to live with a substantial portion of the bio-waste of these visitors. The situation worsens during the rainy season. When it rains, the entire area gets flooded. The canal overflows and black filth gets deposited in courtyard.

The people of Chakkamkandam used to cultivate Pokkali rice (a salinity-resistant rice variety raised in water-logged fields) on both sides of the lake. The banks of the lake were then dotted with coir looms. The scene changed some 25 years ago with the mushrooming of lodges and hotels in Guruvayur to cater to the needs of the rapidly increasing number of pilgrims. High levels of contamination have made farming impossible. Skin diseases and allergy conditions are common among residents of the village. The fish resources are also fast depleting. Valiyathodu (the canal leading to the backwaters) has become a breeding centre for mosquitoes and the putrefaction of wastes takes place all along the course of the canal. Chakkamkandam backwaters have been partially filled with the sludge from the decomposition of the night soil.

Another issue that found in Guruvayur is the dumping of municipality wastes at Choolpuram nearby locality in Guruvayur City. Guruvayur over decades is posing a grave threat to people's lives. The environment is highly polluted and there is a stinking smell all over. The drinking water in all the wells is seriously contaminated because of the pollution and it is not drinkable even after boiling due to large presence of bacteria.

\section{Methodology}

\section{Study Area}

Guruvayur is a municipal town in Thrissur District, of Kerala State in India. Water pollution is one of the major environmental problems faced by that township. Chakkamkandam canal (a canal from Guruvayur to Chakkamkandam), Valiyathod and many water bodies in Guruvayur are polluted by the presence of sewage and human excreta, organic wastes, etc. To assess the water quality, thirteen water samples were collected from Guruvayur municipality in which 7 samples were groundwater, 2 samples were public water and 4 samples from surface water bodies. The water sampling locations are depicted in Figure 1 and Figure 2. One of the surface water samples was collected from Guruvayur temple pond and other 3 samples were collected from Chakkamkandam canal, 


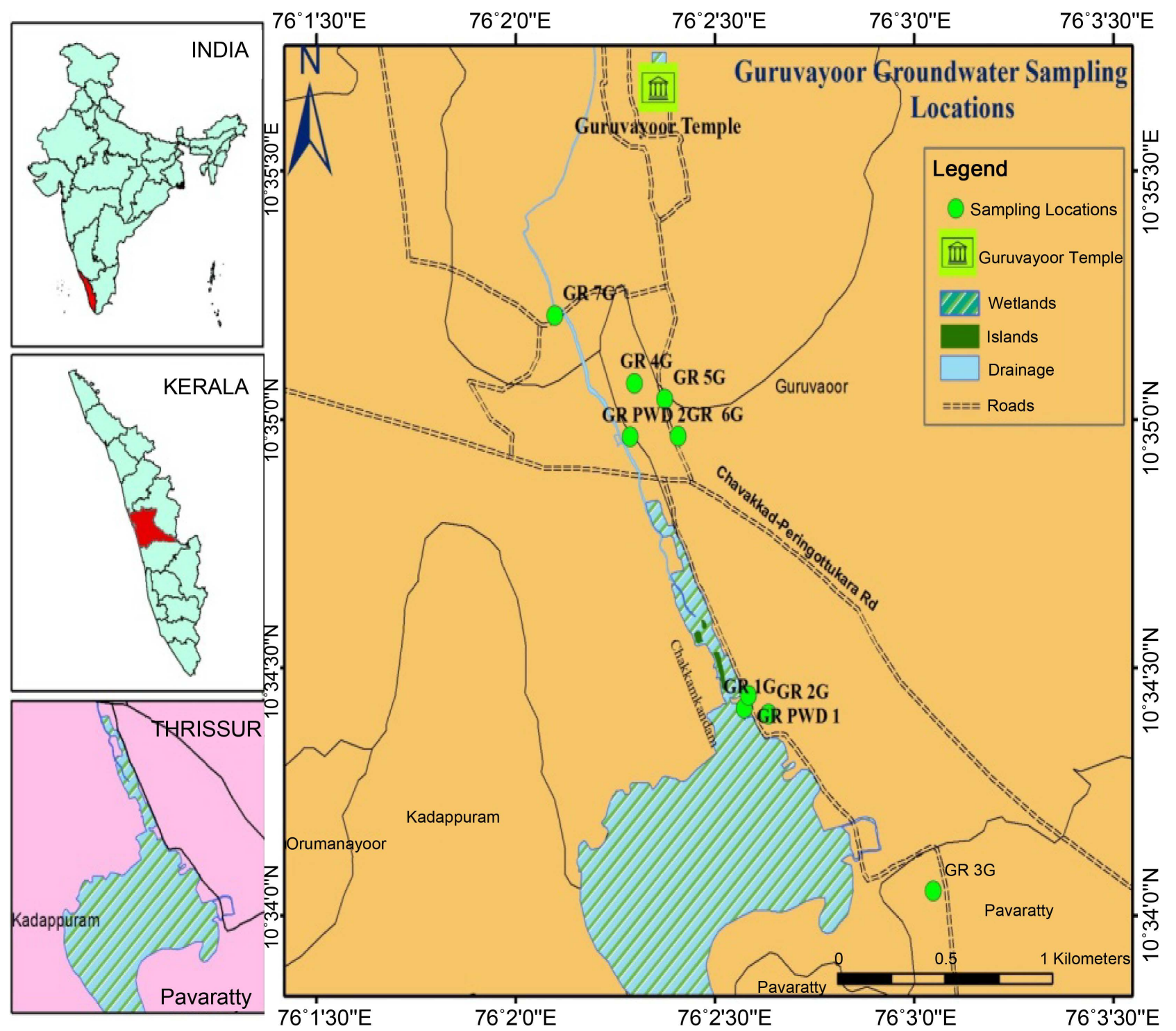

Figure 1. Map showing groundwater sampling location of Guruvayur.

Cheriyathodu and Angadithazham respectively. Seven groundwater samples collected from mainly 3 wards of Guruvayur municipality (Chakkamkandam, Palayur and Edappully).

As a part of the water quality assessment of Guruvayur, a total of 13 samples were collected from different areas of Guruvayur. Random sampling method was done. The containers used for sampling were pre cleaned, non-reactive plastic bottles (1 liter) and sterilized bottles $(100 \mathrm{ml})$ for physico-chemical and bacteriological analysis respectively. Some parameters like $\mathrm{pH}$, temperature, electrical conductivity, TDS, salinity were measured in sites. The samples collected from Guruvayur were analyzed for most of the parameters including physico-chemical and biological parameters as per the standard procedure given in the standard methods for the examination of Water and Wastewater [6].

The groundwater samples, public water samples and surface water sample collected from temple pond were analyzed for the physic-chemical parameters 

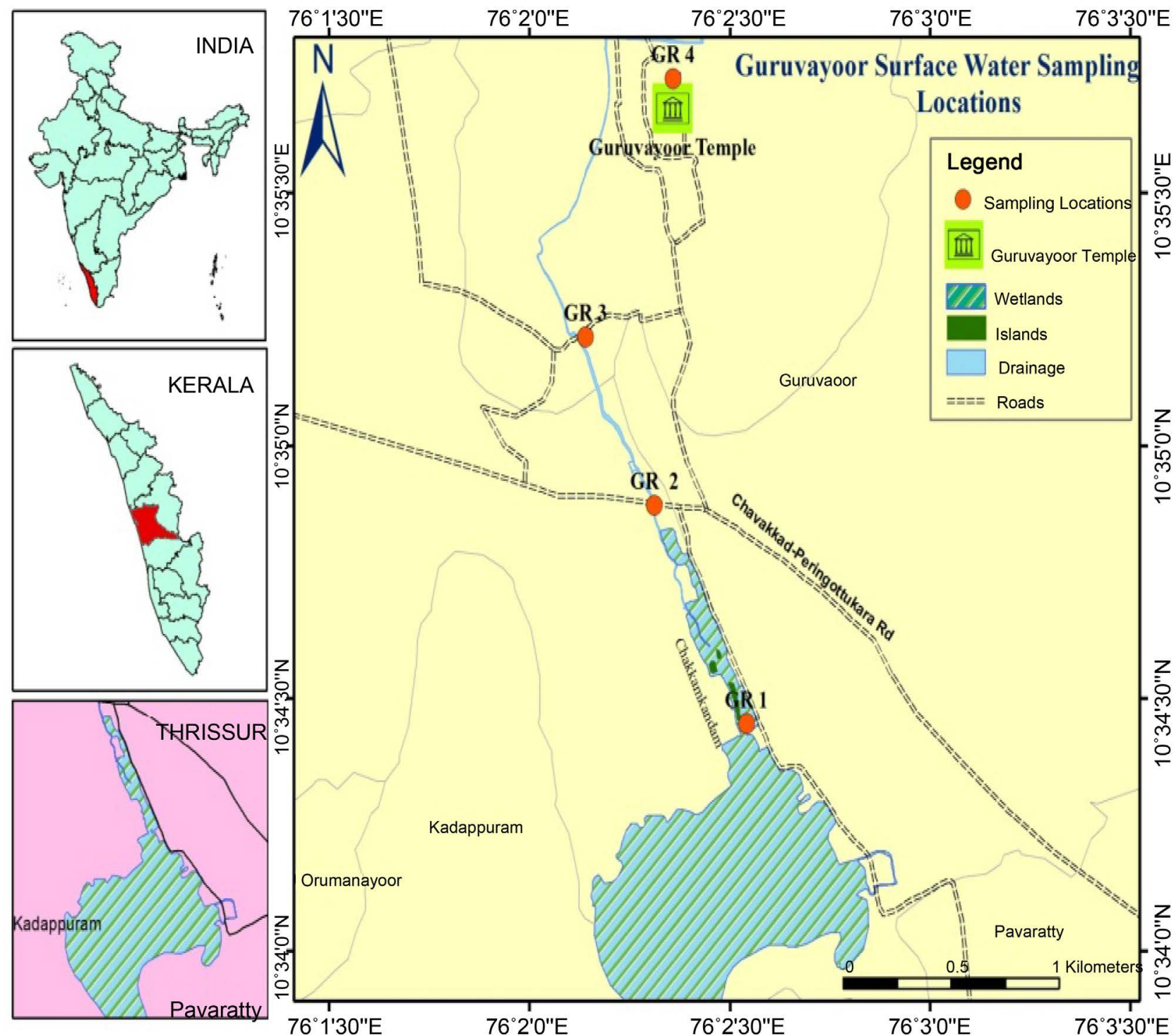

Figure 2. Map showing surface water sampling location of Guruvayur.

such as $\mathrm{pH}$, EC (micro siemens/cm), Temperature $\left({ }^{\circ} \mathrm{C}\right)$, Colour (Hazen), Turbidity (NTU), Total alkalinity (mg/l), TDS (mg/l), Salinity (ppt), Total Hardness(mg/l), Ca (mg/l), Mg (mg/l), Iron (mg/l), Mn(mg/l), $\mathrm{Na}(\mathrm{mg} / \mathrm{l}), \mathrm{K}(\mathrm{mg} / \mathrm{l})$, Chloride (mg/l), Sulphate (mg/l), Nitrate-N (mg/l), Phosphate-P (mg/l) Total Coliform (MPN/100), Faecal coliform, E. coli. Water quality parameters such aspH, EC, TDS, salinity, temperature of the samples were detected using Eu Tech multiparameter analysis meter. The values of turbidity and sulphate were detected using Nephelo turbidity meter. Colour of the samples was determined by visual comparison method. Total alkalinity of the samples was measured by acid-base titration. Total hardness, $\mathrm{Ca}$ and $\mathrm{Mg}$ concentrations of the samples were determined by complexometric titration. Concentration of chloride of the samples was determined by Argentometric titration method. The values of iron, phosphate and nitrate of the collected samples were determined by UV-Visible spectrophotometer. Concentrations of sodium and potassium of the sample were 
detected by flame photometer. The amount of manganese was measured by atomic absorption spectrophotometry.

The surface water samples, collected from Guruvayur municipality were analyzed for DO, BOD, COD, TSS and Oil and grease in addition to other physico-chemical and bacteriological parameters such as total coliform, faecal coliform and E. coli of the samples were analyzed by Multiple Tube Dilution Techniques (MTD Techniques).

\section{Results and Discussion}

The results of the physic-chemical characteristics of the groundwater samples are given in Table 1.

The results of the samples were compared with Bureau of Indian Standards for drinking water quality guidelines (Table 2). $\mathrm{pH}$ of the groundwater samples ranged from 6.24 to 8.55 which indicates that samples were in the acceptable limit as per BIS for drinking water. Most of the groundwater samples have high values of EC especially, water samples taken from Chakkamkandam and Palayur

Table 1. Physicochemical and bacteriological characteristics of groundwater samples.

\begin{tabular}{|c|c|c|c|c|c|c|c|c|c|}
\hline Parameters & $\begin{array}{l}\text { GR } \\
1 G\end{array}$ & $\begin{array}{l}\text { GR } \\
2 \mathrm{G}\end{array}$ & $\begin{array}{l}\text { GR } \\
3 G\end{array}$ & $\begin{array}{l}\text { GR } \\
4 G\end{array}$ & $\begin{array}{l}\text { GR } \\
5 \mathrm{G}\end{array}$ & $\begin{array}{l}\text { GR } \\
6 G\end{array}$ & $\begin{array}{l}\text { GR } \\
7 G\end{array}$ & $\begin{array}{c}\text { GR } \\
\text { PWD1 }\end{array}$ & $\begin{array}{c}\text { GR } \\
\text { PWD2 }\end{array}$ \\
\hline $\mathrm{pH}$ & 6.24 & 6.53 & 6.27 & 6.61 & 6.66 & 6.81 & 8.55 & 7.30 & 7.34 \\
\hline $\mathrm{EC}(\mu \mathrm{s} / \mathrm{cm})$ & 1622 & 945 & 630 & 2420 & 2310 & 757 & 665 & 427 & 428 \\
\hline Temperature $\left({ }^{\circ} \mathrm{C}\right)$ & 28.4 & 29.5 & 28.8 & 31.7 & 28.7 & 29.1 & 29.5 & 32.9 & 32.2 \\
\hline Colour (Hazen) & 1 & 3 & 2.8 & 5 & 9.3 & 3.6 & BDL & 1 & 1 \\
\hline Turbidity (NTU) & 0.5 & 2.5 & 1. 6 & 3.5 & 5.5 & 2.4 & $\mathrm{BDL}$ & 0.4 & 0.5 \\
\hline Total alkalinity $(\mathrm{mg} / \mathrm{l})$ & 131.92 & 131.92 & 89.24 & 190.12 & 267.72 & 131.92 & 97 & 89.24 & 89.24 \\
\hline TDS (mg/l) & 1150 & 661.5 & 447 & 1710 & 1560 & 537 & 472 & 303 & 304 \\
\hline Salinity (ppt) & 0.476 & 0.281 & 0.190 & 0.731 & 0.690 & 0.228 & 0.200 & 0.129 & 0.130 \\
\hline Total Hardness (mg/l) & 265.2 & 122.4 & 106.8 & 550.8 & 306 & 114.24 & 110.16 & 93.84 & 89.76 \\
\hline Calcium (mg/l) & 73.44 & 40.8 & 29.38 & 122.4 & 48.96 & 27.74 & 32.64 & 22.85 & 22.85 \\
\hline Magnesium(mg/l) & 19.83 & 4.96 & 7.93 & 59.49 & 44.61 & 10.91 & 6.94 & 8.92 & 7.93 \\
\hline Iron $(\mathrm{mg} / \mathrm{l})$ & $\mathrm{BDL}$ & 0.4 & BDL & 0.7 & 2.1 & 0.2 & BDL & $\mathrm{BDL}$ & BDL \\
\hline Manganese (mg/l) & 0.01 & $\mathrm{BDL}$ & $\mathrm{BDL}$ & 0.01 & $\mathrm{BDL}$ & $\mathrm{BDL}$ & $\mathrm{BDL}$ & $\mathrm{BDL}$ & $\mathrm{BDL}$ \\
\hline Sodium (mg/l) & 204.8 & 113.2 & 42.15 & 422.2 & 340 & 84 & 42.31 & 20.39 & 19.49 \\
\hline Potassium (mg/l) & 8.5 & 8.5 & 3.67 & 46 & 16 & 7.6 & 13.24 & 2.83 & 2.82 \\
\hline Chloride (mg/l) & 328.20 & 153.42 & 62.14 & 901.09 & 514.44 & 77.72 & 66.62 & 29.61 & 29.61 \\
\hline Sulphate $(\mathrm{mg} / \mathrm{l})$ & 146 & 43.2 & 27.96 & 242.4 & 95.2 & 4.88 & 20.72 & 2.64 & 2.88 \\
\hline Nitrate-N (mg/l) & 0.38 & 0.36 & 0.09 & 0.85 & 1.41 & 0.58 & 0.07 & 0.16 & 0.17 \\
\hline Phosphate-P (mg/l) & 0.04 & BDL & 0.21 & 0.01 & 0.14 & 0.12 & 0.04 & 0.02 & 0.08 \\
\hline Total Coliform (MPN/100) & $\geq 2400$ & $\geq 2400$ & $\geq 2400$ & $\geq 2400$ & 1100 & $\geq 2400$ & 1100 & 460 & 460 \\
\hline Faecal coliform & $\geq 2400$ & $\geq 2400$ & $\geq 2400$ & $\geq 2400$ & 210 & 1100 & 1100 & 210 & 240 \\
\hline E. coli & \multicolumn{9}{|c|}{ Present Present Present Present Present Present Present Present Present } \\
\hline
\end{tabular}


Table 2. Acceptable limits for different drinking water quality parameters prescribed by BIS (IS 10500-2012).

\begin{tabular}{cc}
\hline Parameters & Acceptable limit \\
\hline pH value & $6.5-8.5$ \\
Colour (Hazen) & 5 \\
Turbidity, NTU & 1 \\
Total Dissolved Solids (TDS) (mg/l) & 500 \\
Total alkalinity (mg/l) & 200 \\
Total hardness (mg/l) & 200 \\
Calcium (mg/l) & 75 \\
Magnesium (mg/l) & 30 \\
Chloride (mg/l) & 250 \\
Sulphate (mg/l) & 200 \\
Nitrate (mg/l) & 45 \\
Iron (mg/l) & 0.3 \\
Total Coliform (MPN/100) & Absent \\
Faecal coliform & Absent \\
E. coli & Absent
\end{tabular}

region. The factors that influence the degree of conductivity of water are concentration and mobility of the ions and temperature of water. The concentration of ions like $\mathrm{Na}^{+}$and $\mathrm{K}^{+}$were higher in groundwater samples collected from Chakkamkandam and Palayur. It may be due to the presence of marine water adjacent to these locations.

High TDS values were observed in groundwater samples which were collected from Chakkamkandam and Palayur (GR-1G, GR-4G and GR-5G). Primary sources for TDS in receiving waters are agricultural and residential runoff, leaching of soil contamination and point source of water pollution discharge from sewage treatment plants and also higher concentration of sodium and potassium which can increase the TDS value of samples.

In most of the groundwater samples, values of turbidity exceeded the acceptable limit. The colloidal size particles cause the liquid to appear turbid. Turbidity in open water may be caused by the growth of phytoplankton and also it may be caused by urbanized areas that contribute large amounts of turbidity to nearby waters, through storm water pollution from paved surfaces such as roads, bridges and parking lots.

In groundwater samples collected from Guruvayur municipality, only the value of colour of the sample GR-5G exceeded the safe limit. The colour of the sample was pale brown which indicated the presence of iron in water (insoluble ferric iron). The presence of iron is due to geological origin. The soluble ferrous iron will be oxidized to ferric iron when contact with air and will precipitate as brown or red deposits.

High value of total alkalinity was reported in groundwater sample GR-5G.It might have occurred due to the presence of calcium carbonate or other com- 
pounds such as magnesium carbonate, that contribute carbonate ions to the buffering system. Alkalinity is often related to hardness because the main source of alkalinity is usually from carbonate rocks (limestone) which are mostly Ca$\mathrm{CO}_{3}$. If $\mathrm{CaCO}_{3}$ actually accounts for most of the alkalinity, hardness in $\mathrm{CaCO}_{3}$ is equal to alkalinity. The value of hardness of the sample GR-5G was also exceeded the safe limit. From this it can be understand that there was a direct relationship between alkalinity and hardness.

The two main cations that cause water hardness are $\mathrm{Ca}$ and $\mathrm{Mg}$. Hard water contains dissolved $\mathrm{Mg}$ and $\mathrm{Ca}$ ions. These make it more difficult for the water to form lather with soap. Temporary hardness is caused by dissolved calcium hydrogen carbonate (which can be removed by boiling). Permanent hardness is caused by dissolved calcium sulfate (which cannot be removed by boiling). In the case of Guruvayur municipality the values of total hardness of samples GR-1G, GR-4G, exceeded the permissible limit.

Similar to hardness, the concentration of chloride in groundwater samples GR-1G, GR-4G and GR-5G exceeded the acceptable limit in drinking water. Chloride salts such as sodium chloride, potassium chloride, magnesium chloride are often soluble in water. Wastewater may sometimes contain chloride. Chloride may get into surface water from waste water from municipalities or from saline water bodies. Guruvayur, which is an area adjacent to Chavakkad coastal area, has a possibility to have high concentration of sodium and chloride. These samples collected from Guruvayur, reported to have chloride concentration beyond the permissible limit. Among these three samples, GR-4G has high concentration of chloride. The values of sodium and potassium in groundwater samples of GR-4G and GR-5G was high.

Sulfate is a constituent of TDS and may form salts with $\mathrm{Na}, \mathrm{K}, \mathrm{Ca}, \mathrm{Mg}$ and other cations. In the case of GR-4G, values of $\mathrm{Ca}$ and $\mathrm{Mg}$ exceeded the acceptable limit and also the value of sulphate was high in GR-4G. A positive correlation was observed between $\mathrm{Ca}, \mathrm{Mg}$ with sulphate.

Manganese, nitrate and phosphate values of groundwater samples of Guruvayur municipality were within the acceptable limit.

Groundwater samples collected from stations such as GR-2G, GR-3G, GR-6G, and GR-7G were used by the people for drinking, cooking and bathing purposes. But in those samples, only GR-3G was comparatively less contaminated when compared to other samples. The people of Chakkamkandam and Palayur were not using the well water for domestic purpose (i.e. samples GR-1G, GR-4G, and GR-5 G). Most of the people of Guruvayur depend on public (municipality) water for drinking and cooking purposes.

Two samples collected from Guruvayur public water supply scheme were found to be contaminated with coliform bacteria. Faecal coliform and E. coli was also present in the samples. A total of 4 surface water samples were collected from Chakkamkandam, Palayur, Edappully and Sree Krishna temple pond, Guruvayur. The results of analysis of samples collected from temple pond are shown in Table 3 . Analysis of various water quality parameters were carried out 
Table 3. Bacteriological and physico-chemical characteristics of Guruvayur-temple water.

\begin{tabular}{|c|c|}
\hline Parameters & GR-4 \\
\hline $\mathrm{pH}$ & 8.45 \\
\hline EC (micro siemens/cm) & 1314 \\
\hline Temperature $\left({ }^{\circ} \mathrm{C}\right)$ & 34.2 \\
\hline Colour (Hazen) & 4 \\
\hline Turbidity (NTU) & 3 \\
\hline Total alkalinity $(\mathrm{mg} / \mathrm{l})$ & 38.8 \\
\hline TDS (mg/l) & 931 \\
\hline Salinity (ppt) & 400 \\
\hline Total Hardness (mg/l) & 383.52 \\
\hline Calcium (mg/l) & 130.6 \\
\hline Magnesium (mg/l) & 13.880 \\
\hline Iron (mg/l) & $\mathrm{BDL}$ \\
\hline Manganese (mg/l) & 0.017 \\
\hline Sodium (mg/l) & 99.4 \\
\hline Potassium (mg/l) & 31.8 \\
\hline Chloride (mg/l) & 699.45 \\
\hline Sulphate (mg/l) & 32.28 \\
\hline Nitrate-N (mg/l) & 1.56 \\
\hline Phosphate-P (mg/l) & 0.08 \\
\hline Total Coliform (MPN/100) & $\geq 2400$ \\
\hline Faecal coliform & $\geq 2400$ \\
\hline E. coli & Present \\
\hline $\mathrm{COD}(\mathrm{mg} / \mathrm{l})$ & 80 \\
\hline $\mathrm{DO}(\mathrm{mg} / \mathrm{l})$ & 8.316 \\
\hline BOD $(\mathrm{mg} / \mathrm{l})$ & 2.178 \\
\hline TSS (mg/l) & 51 \\
\hline Oil and Grease $(\mathrm{mg} / \mathrm{l})$ & 98 \\
\hline
\end{tabular}

for the surface sample collected from Guruvayur. The $\mathrm{pH}$ of the sample was 8.45 which was within the acceptable limit set by Bureau of Indian Standards (BIS). (The acceptable limit for various parameters as per BIS is given in Table 4). The sample was green in colour $(4 \mathrm{~Hz})$. It may be due to the presence of algae in sample. In the case of temple pond water, the values of, nitrate, phosphate, $\mathrm{Mg}$, iron, manganese, and alkalinity were within the acceptable limit. The concentrations of cations like calcium, sodium, potassium were high in temple pond. The high concentration of cations increases the value of TDS, EC, and Hardness of the sample. The value of turbidity exceeded the acceptable limit. The cause of turbidity is due to the suspended clay particles.

The water in the temple pond is used for bathing purpose only. The physico-chemical and bacteriological quality characteristics of water samples are shown in Table 2. According to СРСВ (Central Pollution Control Board) out of 
Table 4. Bacteriological and physico-chemical characteristics of surface water samples.

\begin{tabular}{cccc}
\hline Sample code & GR-1 & GR-2 & GR-3 \\
\hline pH & 7.78 & 7.34 & 7.09 \\
TDS $(\mathrm{mg} / \mathrm{l})$ & 4550 & 931 & 4870 \\
Salinity $(\mathrm{ppt})$ & 2.07 & 2.23 & 2.07 \\
EC $(\mu \mathrm{s} / \mathrm{cm})$ & 6170 & 6720 & 6890 \\
COD $(\mathrm{mg} / \mathrm{l})$ & 3600 & 1720 & 920 \\
DO $(\mathrm{mg} / \mathrm{l})$ & 6.138 & Nil & Nil \\
BOD $(\mathrm{mg} / \mathrm{l})$ & 132 & 145.2 & 66 \\
TSS (mg/l) & 320 & 244 & 104 \\
Oil and Grease (mg/l) & 146.8 & 149.6 & 112.4 \\
Totalcoliform (MPN/100) & $\geq 2400$ & $\geq 2400$ & $\geq 2400$ \\
Faecal coliform & $\geq 2400$ & $\geq 2400$ & $\geq 2400$ \\
E. coli & Present & Present & Present \\
\hline
\end{tabular}

the several uses of water of a particular body, the use which demands highest quality is termed its designated best use. One of the five designated best uses identified by СРCB was water for bathing (class B). The bathing water quality of Guruvayur temple pond was determined by comparing the СРСB guidelines. According to CPCB, the amount of dissolved oxygen shall be $5 \mathrm{mg} / \mathrm{l}$ or more in bathing water. In temple pond, dissolved oxygen was $8.316 \mathrm{mg} / \mathrm{l}$. The safe limit of biological oxygen demand is $3 \mathrm{mg} / \mathrm{l}$ or less. In sample GR-4, the value of BOD was $2.178 \mathrm{mg} / \mathrm{l}$ which is within the acceptable limit. But the total coliform content of the sample was more than 2400 which exceeded the safe limit (500 MPN/ $100)$ and also the sample was contaminated by $E$. coli. TSS value of sample was $51 \mathrm{mg} / \mathrm{l}$. The value of oil and grease present in sample was $98 \mathrm{mg} / \mathrm{l}$ which is higher than the acceptable limit.

\section{Surface Water Analysis Report}

Three surface water samples were collected from Chakkamkandam canal, near Chakkamkandam Lake, Palayur and Edappully. The analytical reports of the 3 samples are shown in Table 4. The results are shown in table. The $\mathrm{pH}$ of the surface water samples were within the acceptable limit. The sample GR-1 and GR-2 collected from wetland receives the effluent from the drainage. The sample GR-3 was collected from drainage. The values of electrical conductivity, TDS, salinity of the surface water sample exceeded the permissible limit. The sample GR-1 has high value of COD and the values of COD of all other samples exceeded the permissible limit set by CPCB. The high value of COD in surface sample may be due to the presence organic pollutants or wastes and also the value of oil and grease of the samples were found to be beyond the limit. The surface water of Guruvayur was contaminated by E coli. It may be due to the discharge of untreated domestic, commercial effluents, excreta, human and non-human organic waste from 110 old lodges and a number of marriage audi- 
toriums, restaurants, into the drainage, which flows from Guruvayur. Because of this TSS values of the samples were also higher than the permissible limit.

In surface water sample GR-1 the value of dissolved oxygen was $6.14 \mathrm{mg} / \mathrm{l}$, which is within the limit. But dissolved oxygen was absent in sample GR-2 and GR-3. Low dissolved oxygen (DO) may be the results of excessive algae growth caused by phosphorus and nitrogen. Die-off and decomposition of submerged plants also contributes to low dissolved oxygen. Sources of phosphorus include discharges from municipal and private wastewater treatment. Direct discharge of pollutants from point source and nonpoint sources into water bodies decrease DO below acceptable concentrations.

The values of BOD of sample GR-1 was maximum and all other samples have the BOD value above the permissible limit. Natural organic detritus and organic waste from waste water treatment plants, failing septic systems and agricultural and urban runoff, acts as a food source for water-borne bacteria. Bacteria decompose these organic materials using dissolved oxygen, thus reducing the DO present for fish. Biochemical oxygen demand (BOD) is a measure of the amount of oxygen that bacteria will consume while decomposing organic matter under aerobic condition. Thus the high value of BOD of sample may be due to the presence of high amount of pollutants in samples.

\section{Conclusion}

The results of the current study indicated the chemical and bacteriological contamination due to the disposal of solid, organic and septic wastes in the surface water samples of Chakkamkandam, Palayur and Edappally which are the various locations in Gurauvayur. The sewage inlets that open directly to the water body are the major source of pollutants. There are both point and non-point sources of pollution which are leading to pollution of various water bodies of Guruvayur. Also the groundwater samples of Guruvayur were contaminated. The study revealed that, the characteristics of water samples examined were not within the limits prescribed by BIS. The monitoring of various water bodies indicates the importance of taking appropriate measures to treat the water resources before either discharged to wetlands or consumed by human beings. It is also recommended to continue the monitoring periodically to assess the pollution status of the area.

\section{References}

[1] Environmental Issues of Kerala in General and Kochi/Ernakulam in Particular (2016).

http://www.indiaenvironmentportal.org.in/files/file/environmental\%20issues $\% 20$ of \%20kerala.pdf

[2] Oketola, A.A., Adekolurejo, S.M. and Osibanjo, O. (2013) Water Quality Assessment of River Ogun Using Multivariate Statistical Techniques. Journal of Environmental Protection, 4, 466 479. https://doi.org/10.4236/jep.2013.45055

[3] Pink, D.H. (2016) Investing in Tomorrow's Liquid Gold. http://finance.yahoo.com:80/columnist/article/trenddesk/3748 
[4] Akinbile, C.O. and Yusoff, M.S. (2011) Environmental Impact of Leachate Pollution on Groundwater Supplies in Akure, Nigeria. International Journal of Environmental Science and Development, 2, 81-86. https://doi.org/10.7763/IJESD.2011.V2.101

[5] Chonattu, J., Prabhakar, K. and Pillai, H.P.S. (2016) Geospatial and Statistical Assessment of Groundwater Contamination Due to Landfill Leachate-A Case Study. Journal of Water Resource and Protection, 8, 121-134.

https://doi.org/10.4236/jwarp.2016.82010

[6] APHA (2012) Standard Methods for the Examination of Water and Waste Water. 22nd Edition, American Public Health Association, American Water Works Association, Water Environment Federation.

Submit or recommend next manuscript to SCIRP and we will provide best service for you:

Accepting pre-submission inquiries through Email, Facebook, LinkedIn, Twitter, etc. A wide selection of journals (inclusive of 9 subjects, more than 200 journals)

Providing 24-hour high-quality service

User-friendly online submission system

Fair and swift peer-review system

Efficient typesetting and proofreading procedure

Display of the result of downloads and visits, as well as the number of cited articles Maximum dissemination of your research work

Submit your manuscript at: http://papersubmission.scirp.org/

Or contact jep@scirp.org 